\title{
THE REASONED ACTION APPROACH TO GROWTH INTENTION TO INCREASE SMALL AND MEDIUM ENTERPRISES: A CONCEPTUAL FRAMEWORK
}

\author{
Annuridya Rosyidta Pratiwi Octasylva ${ }^{*}$,, Lilik Noor Yuliati**), Hartoyo ${ }^{* * *}$, Agus W. Soehadi $\left.{ }^{* * * *}\right)$ \\ ${ }^{*}$ Department of Management, Institut Teknologi Indonesia \\ Jl Raya Puspiptek, South Tangerang 15314, Indonesia \\ ${ }^{* *}$ Department of Family and Consumer Sciences, Faculty of Human Ecology, IPB University \\ J1. Kamper, IPB Dramaga Campus, Bogor 16680, Indonesia \\ ${ }^{* * *}$ School of Business, IPB University \\ Jl. Raya Pajajaran, Bogor 16151, Indonesia \\ ${ }^{* * * *}$ School of Business and Economics, Universitas Prasetiya Mulya \\ Jl. BSD Raya Utama, BSD City, Kabupaten Tangerang 15339, Indonesia
}

\begin{abstract}
Entrepreneurship plays an important role in the economy, among others, in reducing the unemployment rate and improving the economy of a country. However, this was not accompanied by the interest of entrepreneurs in increasing their business. Even though interest is the main predictor in shaping the behaviour and performance of a business. This article aimed to provide literature on what factors can shape an entrepreneur's interest in developing his business. In answering the objectives of this study, a literature study was carried out on the articles about interest in developing a business published in the 2010-2021 period and contained in a bibliographic database. Based on the results of the study, four factors could strengthen the interest in entrepreneurs developing their business, namely: attitude, descriptive norms, injunctive norms and perceived behavioural control with the theoretical approach of reasoned action approach, which are known to be better at predicting behavioural interest because the variables used are more detailed. This research is not only useful for entrepreneurs to increase their demand to develop their business but also useful for related stakeholders to support the increase in-class promotion of MSME actors.
\end{abstract}

Keywords: attitude, descriptive norm, MSME, injunctive norm, perceived behavioural control

\begin{abstract}
Abstrak: Kewirausahaan memainkan peran penting dalam perekonomian antara lain dalam mengurangi tingkat pengangguran dan meningkatkan perekonomian suatu negara. Namun hal ini tidak dibarengi oleh minat para wirausaha dalam meningkatkan usahanya. Padahal minat adalah predictor utama dalam pembentukan perilaku dan kinerja dari suatu usaha. Artikel ini bertujuan untuk memberikan literature faktor faktor apa saja yang dapat membentuk minat wirausahawan dalam mengembangkan usahanya. Dalam menjawab tujuan penelitian ini, studi literatur dilakukan terhadap artikel mengenai minat mengembangkan usaha yang dipublikasikan pada periode 2010-2021 dan terdapat dalam bibliographic database. Berdasarkan hasil penelitian menunjukan terdapat empat faktor yang dapat memperkuat minat dalam pengusaha mengembangkan usahanya, yaitu sikap, Norma deskriptif, Norma Injuctive dan Perceived Behavioral Control dengan pendekatan teori Reasoned Action Approach diketahui lebih baik dalam memprediksi minat berprilaku dikarenakan variable yang digunakan lebih detail. Penelitian ini tidak hanya bermanfaat untuk para wirausaha untuk meningkatkan minta mengembangkan usahanya, tetapi juga bermanfaat bagi stakeholder terkait dalam rangka mendukung peningkatan kenaikan kelas para pelaku UMKM.
\end{abstract}

Kata kunci: sikap, norma deskriptif, UMKM, norma injuctive, perceived behavioral control

\footnotetext{
${ }^{1}$ Corresponding author:

Email: annuridya@yahoo.com
} 


\section{INTRODUCTION}

Entrepreneurship plays a role in improving the economy around the world. This statement is confirmed by Mahfud et al. (2020), which stated that entrepreneurship plays a vital role in economic prosperity, social stability in developing countries. Entrepreneurship is an innovative and creative process, which plays a potential role in creating new and added value for products/ services, increasing productivity, creating new job opportunities, revitalizing and diversifying markets, increasing social welfare, and developing the national economy. According to Guerrero et al. (2008), with its role so crucial, it makes research about entrepreneurship an advanced research issue in the last few years. Entrepreneurs find, identify opportunities, or create and use them to add value to society. Entrepreneurship is considered to identify, evaluate, develop, and utilize opportunities and the resources and conditioners that influence the entrepreneurial process (Sanchez 2014). Entrepreneurial research has become an interesting topic in recent years (Alferaih, 2014). Research on entrepreneurship has been linked to other research fields, such as social and psychology (Gieure et al. 2020). This research topic's development is due to its essential role in the economy to help overcome the unemployment rate, its contribution to social development and economic growth (Mahfud et al. 2020). Dong et al. (2020) the need for an increase in the number of entrepreneurs to accelerate the economy and create ideas to become a profitable business is crucial for entrepreneurship (Turker \& Selcuk 2009).

Answering various world economic problems, especially unemployment and social welfare, can be done through an entrepreneurial approach. Micro, small and medium enterprises (SMEs) answer to this form of entrepreneurship. Where SMEs are central to the collective goals of increasing productive potential, reducing inequality and ensuring that the benefits of increased globalization and technological progress (OECD, 2018). The proportions of micro-enterprises contribute more than $70 \%$ of the overall business (OECD, 2019). This is in line with the statement of Bank Indonesia \& LPPI (2015) that SMEs have a proportion of $99.99 \%$ of Indonesia's total business operators or as many as 56.54 million units. Based on the data, the interest to start a new business (entrepreneurial intention) is relatively high, at $35 \%$ for Indonesia, $12 \%$ for Malaysia. At the same time, SMEs' interest in developing their business is only $4 \%$, which has an orientation to go international (export) by $25 \%$ and wish to have new products or services by $23 \%$ (GEM, 2013). The importance of studying business development is due to the high number of business failures. According to the 2019 GEM report (Bosma \& Kelley, 2019), the high number of businesses stops due to several things such as unprofitable business, the business is sold, bureaucratic issues, and others. The description of the comparison between New Business (TEA-Total Earlystage Entrepreneurial Activity) with outgoing business can be seen in Figure 1.

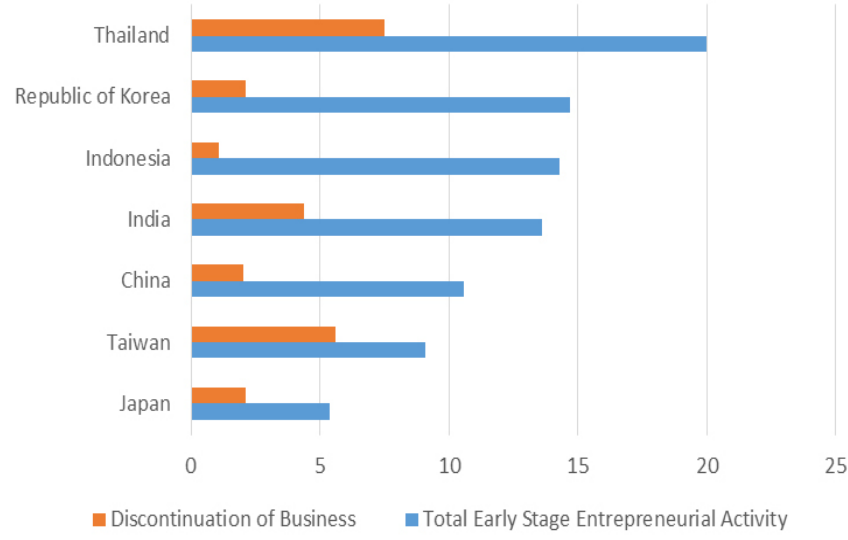

Figure 1. The comparison between new business with outgoing business

Growth intentions cannot be used in terms of economic development if such intentions are not followed up. Thus, an understanding of how the impact of growth in intentions on actual SME growth can significantly add to the value of the existing literature on SMEs' growth in South Africa (Neneh \& Vanzyl, 2014). This research is critical because it is hoped that developing a business is the first step before creating business activities, where this intention is a predictor in conducting activities. Mahfud et al. (2020) stated that developing entrepreneurial interests is a crucial issue if we want to provide solutions to the unemployment problem. Thus, knowing the factors that shape an entrepreneurial interest is very important. This is reinforced by Fayolle \& Linan (2014), which stated that understanding entrepreneurial intentions will make a significant contribution to the decision making process at the personal level, wherein this case, it is possible to provide a more effective design of Education design, initiatives, and models of this interest can be an evaluation tool.

There are two theoretical approaches in predicting entrepreneurial interest, namely through the Theory of Planned Behavior (TPB) approach (Ajzen, 1991) 
and the Entrepreneur Event Model (EEM) (Shapero, 1982). Similar to TPB, the EEM model offers three antecedents (variables) to predict entrepreneurial intentions, which consist of perceptions of desires, perceptions of worthiness and inclinations to act. These two theories have contributed significantly to the study of entrepreneurial intentions, and both have relationships and similarities. Schalaegel \& Koenig (2014) mentioned that the two theories are partly integrated. Mahfud et al. (2020) revealed that the two models have differences, especially the EEM model does not consider social factors' role. In contrast, TPB is formed from the antecedents (variables) attitudes, subjective norms and control of accepted behaviour. Based on these two models, TPB and EEM, it can be seen that the factors forming entrepreneurship consist of three factors: attitude, social, and psychological dimensions.

Over time, there have been developments in predicting behaviour, which is the development of TPB theory. Ajzen developed the TPB theory by distinguishing between different subcomponents of attitudes, subjective norms, and behavioural control constructs perceived in TPB. These theories' popularity is due to their relative simplicity and relative flexibility and their effectiveness in accounting for substantial differences in behaviour. These theories also serve as the basis for broad approaches that include new constructs towards developing more comprehensive behavioural explanations and testing essential processes that determine actions such as the relationship between intention and behaviour. This study provides an overview of various factors associated with determinate growth intention, such as attitude, injunctive norm, subjective norm and perceived behaviour control. Finally, based on analysis, it categorizes the factors and proposes a conceptual framework using the Reasoned Action Approach (RAA). Thus, the study enhances the existing literature's understanding to build a conceptual framework about growth intention.

\section{METHODS}

This paper is based on the data collected through secondary literature sources related to growth intention published in the last ten years (2010-2020), using keywords such as "reasoned action approach". We identified 128 potentially relevant publications, including papers, editorial, book chapters and other literature. Book chapters, encyclopedia, reports, thesis and unpublished manuscripts and double papers/ studies with missing information excluded too. The data collection technique in this research can be said with a literature study.

RAA is a new theory introduced by Ajzen and Fishbein in 2010. This theory is a development of TPB where in RAA, three determinants of intention are labelled attitudes toward behaviour, perceived norms, and perceived behavioural control (PBC), each represented by a different pair of subcomponents - but related. The systematic image of RAA can be seen in Figure 2.

In RAA, behavioural intention (or "readiness to conduct behaviour") is "the best single indicator in shaping behaviour" (Fishbein \& Ajzen, 2011). Behavioural intentions, together with essential skills and abilities and environmental factors (actual external resources and obstacles on behavioural performance), influencing behaviour. In RAA, behavioural intention is influenced by direct and indirect determinants. Direct determinants of behavioural intentions include attitudes (tendency to respond with a degree of liking to psychological objects) towards behaviour, norms (acceptable behaviour in groups or community) to conduct behaviour, and control perceived behaviour (PBC; perception of one's control over a behaviour). Based on McEachan et al. (2016), each construct of intention formation, namely attitude, perceptive norm and perceived Behavior control, is formed from 2 sub-components. Specifically, attitudes toward behaviour are assumed to consist of experience and instrumental attitudes; perceived norms are considered to consist of injunctive and descriptive norms, whereas PBC is assumed to consist of capacity and autonomy. Ajzen et al. (2007) have suggested that subcomponents reflect more general constructs (e.g., experiences and instrumental attitudes reflect overall attitudes toward a behaviour) and that more general constructs are used in analyzing (e.g., second-order factor analysis models).

In economic theory, while growth is viewed as a natural phenomenon that occurs until profit is maximized nevertheless, in reality, not all SMEs owners want to grow their businesses to maximize (Neneh \& Vanzyl, 2014). Growth is a combination of what the actor wants with entrepreneurs and opportunities' critical resources and skills. Neneh \& Vanzyl (2014) classified the factors that determine the growth intention of business into several categories: entrepreneur demographics (gender, age, education, family experience); the entrepreneur's context (startup motivation, desire to succeed, desire 
to be one's boss and the desire to be independent, opportunity recognition); firm attribute (size and innovation); the individual skills of the entrepreneur (managerial skills, technical skills, practical skills, career experience, serial entrepreneurship and patenting); psychological characteristics (risk-taking propensity, the need-for-achievement, goal setting, self-efficacy and tolerance of ambiguity) and external environmental factors such as government policies (availability of government's assistance, training programs and support service, taxes, procedural requirements for registration), organizational factors (innovative climate and incentives). All of the factors above will contribute to the entrepreneur's decision to shape their interest in developing the business. In this paper, the analysis of intention determinants was conducted from the psychological side with the RAA approach.

The independent variables in this study were attitude, injunctive norms, descriptive norms, and $\mathrm{PBC}$, while the dependent variable was growth intention. Questionnaires were used to obtain the value of each variable and can then be processed using descriptive analysis (Rosiana et al. 2020). All of these independent variables were considered to be the basis for determining and describing the development of intention.

\section{RESULTS}

The use of RAA theory in predicting entrepreneurial development intentions is something new. This can be seen from the results of the processing of VOS with the keyword "reasoned action approach" obtained by 31 articles since 2010 about direct science as follows in
Figure 3. This is to make it easier to map the concept of the variables used in the study.

To develop the conceptual framework, we selected 18 papers shown in the Table 1. The model of developing an interest through the RAA approach can be seen in Figure 4. This figure is used as the basis for determining the relationship of each variable from the point of view of the research hypothesis. The relationship between variables and variables is further described in Table 2, in which there is a description of the dimensions of the variables.

From Figure 3, it can be seen that research through the RAA theory approach has a relationship with intention, but the RAA approach has not been made to predict growth intention. Research using the RAA approach is also relatively still scarce and new, where RAA is most widely used in research in 2016 based on the results of overlay visualization of VOS. This provides knowledge that RAA can be used to predict intention. Nevertheless, research that uses this approach in intention is still very rarely seen in Figure 2. The use of RAA theory in this study to predict growth intention has several advantages, namely: variable attitude used includes positive or negative consequences perceived in behaviour. It includes positive or negative experiences felt in conducting behaviour. In TPB, subjective norm or commonly defined as social pressure in carrying out a behaviour. In RAA, the theory is developed into the injunctive norm and descriptive norm. In the injunctive norm, which is a perception of what must or should be done, this is used in TPB as Subjective norm, and Descriptive norm is the perception that other people can or do not perform the intended behaviour.

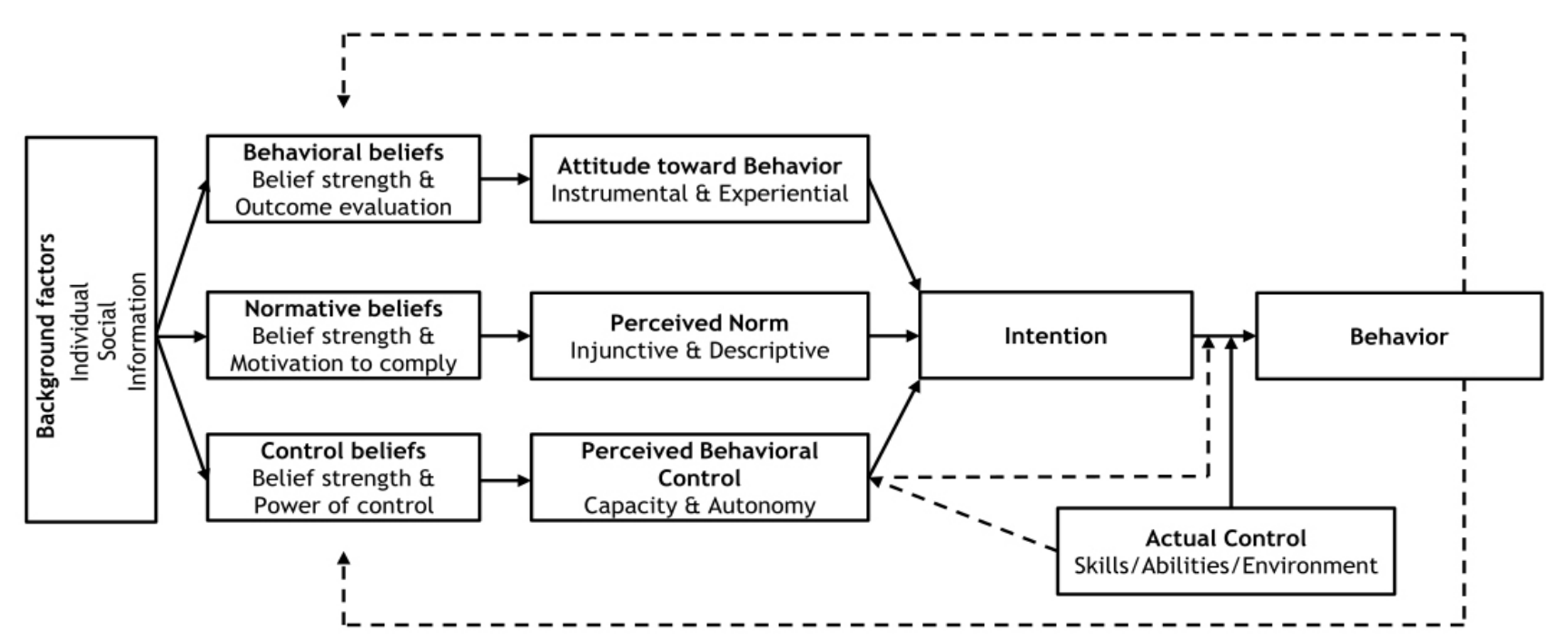

Figure 2. Systematic of RAA 


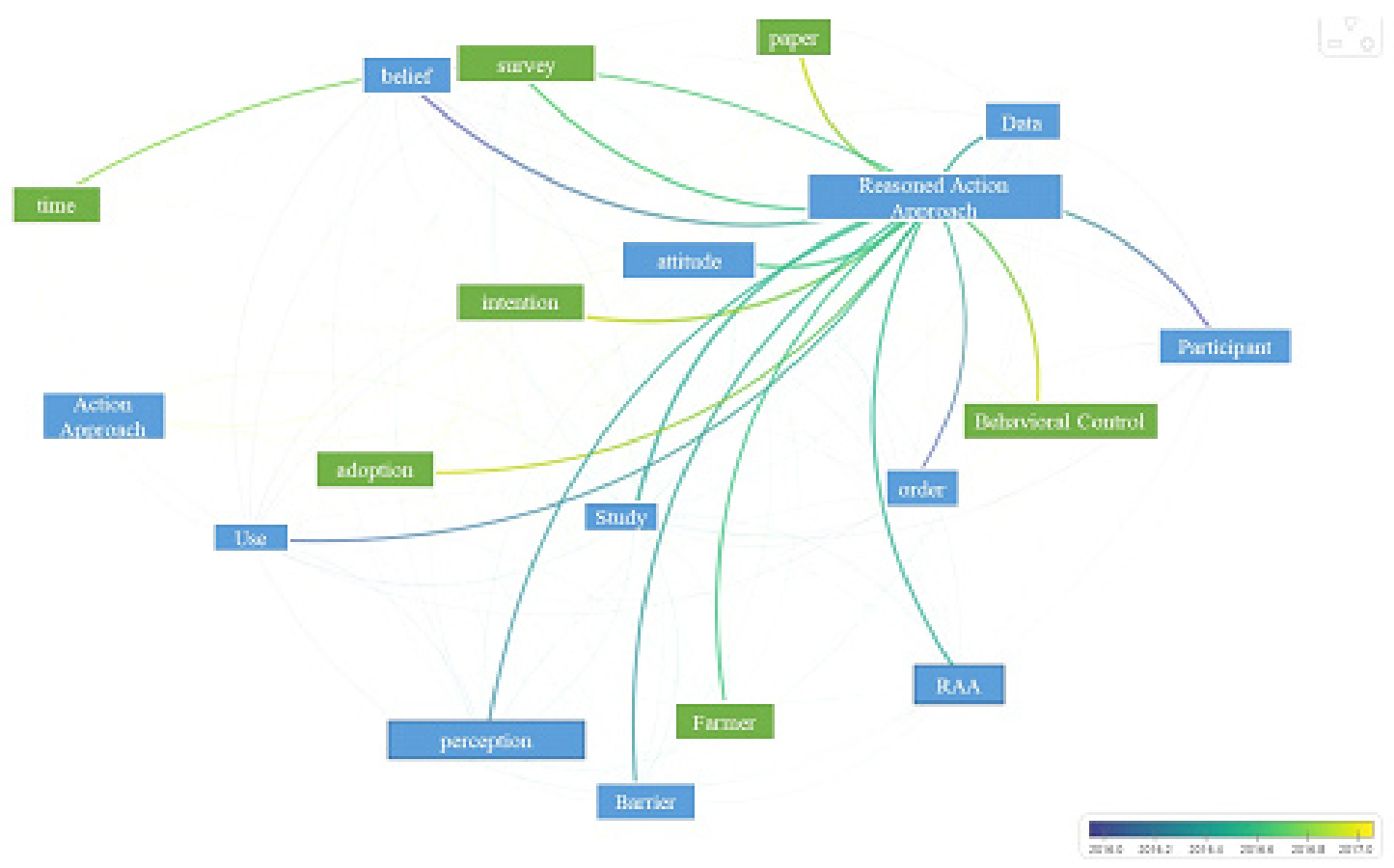

Figure 3. Author keywords co-occurrence results

Table 1. Reference develop the conceptual framework

\begin{tabular}{|c|c|c|c|c|}
\hline Expert (Year) & Method & Object & Variable & Information \\
\hline $\begin{array}{l}\text { Kim et al. } \\
(2013)\end{array}$ & $\begin{array}{l}\text { Structural } \\
\text { Equational } \\
\text { Modeling }\end{array}$ & Food industry & $\begin{array}{l}\text { Subjective norm, Attitude toward } \\
\text { behaviour, Behavior intention }\end{array}$ & $\begin{array}{l}\text { All variables influence } \\
\text { behaviour intention }\end{array}$ \\
\hline $\begin{array}{l}\text { Hussein et al. } \\
\text { (2017) }\end{array}$ & Regression & 400 smarthpone user & Intention \& Attention & Attention affects intention \\
\hline $\begin{array}{l}\text { Wicklund } \\
\text { (2014) }\end{array}$ & $\begin{array}{l}\text { Path } \\
\text { Analysis }\end{array}$ & $\begin{array}{l}\text { Small business "film } \\
\text { industry" }\end{array}$ & $\begin{array}{l}\text { Attitude, entrepreneur resource, } \\
\text { network resource, industry, dynamic, } \\
\text { hostility, heterogeneity }\end{array}$ & Attitudes affects intention \\
\hline $\begin{array}{l}\text { Adrianto } \\
(2020)\end{array}$ & Regression & Coca-Cola lovers & Attitude, intention & $\begin{array}{l}\text { Attitude has a negative } \\
\text { effect on the intention }\end{array}$ \\
\hline $\begin{array}{l}\text { Lee et al. } \\
\text { (2017) }\end{array}$ & $\begin{array}{l}\text { Structural } \\
\text { Equational } \\
\text { Modeling }\end{array}$ & College student & Awareness value, attitude, intention & $\begin{array}{l}\text { All variables have an } \\
\text { influence on attitude }\end{array}$ \\
\hline $\begin{array}{l}\text { Nicolaides } \\
(2011)\end{array}$ & Descriptive & Secondary data & $\begin{array}{l}\text { Environmental, Promoting, Education, } \\
\text { Role }\end{array}$ & $\begin{array}{l}\text { All variables encourage } \\
\text { the formation of } \\
\text { entrepreneurial intentions }\end{array}$ \\
\hline $\begin{array}{l}\text { Miralles et al. } \\
\text { (2012) }\end{array}$ & $\begin{array}{l}\text { Structural } \\
\text { Equational } \\
\text { Modeling }\end{array}$ & $\begin{array}{l}\text { Student and New } \\
\text { Entrepreneurs }\end{array}$ & $\begin{array}{l}\text { TPB model (personal attitude, } \\
\text { subjective attitude, PBC, intention, and } \\
\text { behaviour) }\end{array}$ & $\begin{array}{l}\text { Personal attitude and } \\
\text { PBC affect intentions }\end{array}$ \\
\hline $\begin{array}{l}\text { Rameikiene } \\
\& \text { Startiene } \\
(2013)\end{array}$ & Descriptive & $\begin{array}{l}\text { College students in } \\
\text { University (Technical } \\
\text { \& Economic Faculty) }\end{array}$ & Start a business & $\begin{array}{l}\text { The majority of students } \\
\text { are ready to start when } \\
\text { they finish college }\end{array}$ \\
\hline $\begin{array}{l}\text { Niewenhuizen } \\
\& \text { Swanepoel } \\
\text { (2015) }\end{array}$ & Descriptive & College students & $\begin{array}{l}\text { Intent, personal attitude, } \mathrm{PBC} \text {, value, } \\
\text { knowing, assistance, managing support, } \\
\text { marketing and networking, financial } \\
\text { acumen, entrepreneurial competencies }\end{array}$ & $\begin{array}{l}\text { The majority of } \\
\text { behaviour can be formed } \\
\text { when it has an intention }\end{array}$ \\
\hline Wong (2019) & Regression & $\begin{array}{l}\text { Undergraduates } \\
\text { Student }\end{array}$ & $\begin{array}{l}\text { Comparison between revised TPB \& } \\
\text { classic TPB }\end{array}$ & $\begin{array}{l}\text { Descriptive norm is an } \\
\text { important variable to } \\
\text { affect the intention }\end{array}$ \\
\hline
\end{tabular}


Table 1. Reference develop the conceptual framework (continue)

\begin{tabular}{|c|c|c|c|c|}
\hline Expert (Year) & Method & Object & Variable & Information \\
\hline $\begin{array}{l}\text { Smith et al. } \\
(2012)\end{array}$ & $\begin{array}{l}\text { Regression } \\
\text { \& ANOVA }\end{array}$ & Students & $\begin{array}{l}\text { Attitude, } \mathrm{PBC} \text {, and interpersonal-level } \\
\text { descriptive, and injunctive norms }\end{array}$ & $\begin{array}{l}\text { There was a significant } \\
\text { difference in the influence } \\
\text { of the UK and Chinese } \\
\text { students on their } \\
\text { attitude toward intention } \\
\text { formation }\end{array}$ \\
\hline $\begin{array}{l}\text { Ham et al. } \\
(2015)\end{array}$ & Regression & 411 Household & $\begin{array}{l}\text { Personal attitude, Subjective norm } \\
\text { (descriptive norm, social norm), PBC, } \\
\text { and intention }\end{array}$ & $\begin{array}{l}\text { The latter also } \\
\text { empirically proves that } \\
\text { the meaning behind the } \\
\text { two variables (social and } \\
\text { descriptive norms) is } \\
\text { different }\end{array}$ \\
\hline Zeleski (2013) & Regression & Smoker & $\begin{array}{l}\text { Perceived descriptive norm, injunctive } \\
\text { norm }\end{array}$ & $\begin{array}{l}\text { Intention can be formed } \\
\text { due to the environment }\end{array}$ \\
\hline $\begin{array}{l}\text { Farias \& Pilati } \\
(2020)\end{array}$ & Regression & 2056 Participant & $\begin{array}{l}\text { Attitudes, injunctive norms, descriptive } \\
\text { norms, PBC, intention }\end{array}$ & $\begin{array}{l}\text { Attitudes, injunctive } \\
\text { norms, and descriptive } \\
\text { norms affect the intention }\end{array}$ \\
\hline $\begin{array}{l}\text { Schlagel \& } \\
\text { Koening } \\
(2014)\end{array}$ & Regression & 123 Sample & $\begin{array}{l}\text { Perceived desirability, propensity to } \\
\text { act, perceived feasibility, entrepreneur } \\
\text { intention }\end{array}$ & $\begin{array}{l}\text { Perceived desirability, } \\
\text { propensity to act, } \\
\text { perceived feasibility } \\
\text { affecting entrepreneur } \\
\text { intention }\end{array}$ \\
\hline $\begin{array}{l}\text { Kobis et al. } \\
(2015)\end{array}$ & Descriptive & 100 People & Intention \& Descriptive norm & $\begin{array}{l}\text { Descriptive norm } \\
\text { affecting intention }\end{array}$ \\
\hline $\begin{array}{l}\text { Erikson et al. } \\
(2015)\end{array}$ & Descriptive & $\begin{array}{l}\text { Doctoral and } \\
\text { postdoctoral } \\
\text { scientists }\end{array}$ & $\begin{array}{l}\text { Enterprising norm, experience, } \\
\text { moderating effect, intention }\end{array}$ & $\begin{array}{l}\text { Enterprising norm, } \\
\text { experience, moderating } \\
\text { effects affect the intention }\end{array}$ \\
\hline $\begin{array}{l}\text { Mair \& Bergin } \\
(2010)\end{array}$ & Descriptive & Tourism & $\begin{array}{l}\text { Intervention and environmental } \\
\text { behaviour }\end{array}$ & $\begin{array}{l}\text { intention to play a role } \\
\text { in the intervention and } \\
\text { environmental }\end{array}$ \\
\hline
\end{tabular}

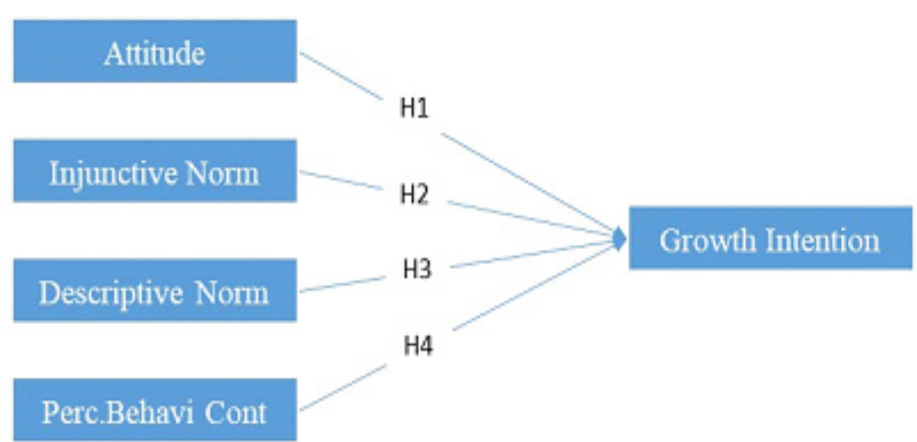

Figure 4. The RAA approach to predict growth intention 
Table 1. Variable \& dimensions

\begin{tabular}{|c|c|c|}
\hline Variables & Description & Dimensions \\
\hline Attitude & $\begin{array}{l}\text { Attitude tendencies } \\
\text { that are formed } \\
\text { in response to } \\
\text { perceptions of } \\
\text { personal desire to } \\
\text { develop a business }\end{array}$ & $\begin{array}{l}\text { Pleasant place } \\
\text { Standard } \\
\text { Time } \\
\text { Consistency } \\
\text { Supplier control } \\
\text { Another position } \\
\text { Security }\end{array}$ \\
\hline $\begin{array}{l}\text { Injunctive } \\
\text { norm }\end{array}$ & $\begin{array}{l}\text { Approval of support } \\
\text { from the nearest } \\
\text { environment } \\
\text { in carrying out } \\
\text { performance } \\
\text { development }\end{array}$ & $\begin{array}{l}\text { Family } \\
\text { Important people } \\
\text { Institution } \\
\text { Environment } \\
\text { Plan }\end{array}$ \\
\hline $\begin{array}{l}\text { Descriptive } \\
\text { norm }\end{array}$ & $\begin{array}{l}\text { Behaviour is triggered } \\
\text { by a person's desire } \\
\text { to act as in general } \\
\text { as others can act on a } \\
\text { situation }\end{array}$ & $\begin{array}{l}\text { Opinion } \\
\text { Proximity } \\
\text { Great fun } \\
\text { Responsible } \\
\text { Focus }\end{array}$ \\
\hline $\begin{array}{l}\text { Perceived } \\
\text { behaviour } \\
\text { control }\end{array}$ & $\begin{array}{l}\text { A person's perception } \\
\text { of how easy or } \\
\text { difficult behaviour is } \\
\text { to do }\end{array}$ & $\begin{array}{l}\text { Confidence } \\
\text { Trust } \\
\text { Success } \\
\text { Knowledge } \\
\text { Consistency }\end{array}$ \\
\hline
\end{tabular}

PBC of perceived behaviour: people's perception of the extent to which they can, or have control over, carrying out certain behaviours. The sub-component of PBC is capacity: the belief that a person can, can or can perform the behaviour in which TPB is known as PCB and autonomy. The RAA approach to determine entrepreneurial growth intention can be divided into four variables: attitude, injunctive norm, descriptive norm, and perceived behaviour control. Indicators that form latent attitude variables in forming entrepreneurial interest can be divided into, namely, creativity, personal benefit, stability, power and independence (Ajzen, 2012). Based on Mueller (2011), an attitude has an occurrence of 107 to predict entrepreneurial intention. Indicators forming the injunctive norm can be adopted with two indicators (Charan et al. 2018): perceived family expectations and significant others' expectations.

In contrast, descriptive norms are formed from indicators of the actual behaviour of essential others. Adopting the indicator from $\mathrm{PBC}$ can be developed from research adoption (Charan et al. 2018). This is also one of the most significant weights of forming entrepreneurial intention in the meta-analysis (Ajzen \& Fishbein, 1980) with an occurrence value of 53 . To build hypotheses on Figure 4, then it can be explained as follows:

\section{Attitude toward Growth Intention}

Attitude has been shown to influence behavioural interest in many studies (Ajzen \& Fisshbein, 1980). Many studies have used the theory of Planned Behavior to model the relationship between Attitude and Intention. The interest/intention of the SMEs is a state or a choice in their common sense and awareness so that in the intention to increase their efforts, the SMEs will carry out an attitude that supports their intention to grow. (Ajzen \& Fisshbein, 1980; Kim et al. 2013), Explain that there are significant and positive results on the relationship between attitude and entrepreneurial interest.

The attitude of the individual can reflect the intention. This can be seen from the reflection of the visible attitude (positive or negative), leading to good and bad intentions (Hussein et al. 2017). When a service provided to consumers is unable to create a positive attitude, improvements are needed in better services (efficient, easily accessible, and safe) so that later attitudes will be positive and form good intentions (Wicklund, 2014). Adrianto (2020) explained that attitude influences intention; this is evidenced by the credibility of the product, the informative attitude described, and the hedonic nature raised to the public.

Lee et al. (2017) found that the intention to buy is due to attitude. Researchers explained that several things can encourage attitudes, including advertising (promotion), the timing of providing information, disturbances that arise and personalization of the individual. Nicolaides (2011) explained that a person's attitude needs to be evaluated to determine the initial assessment (positive or negative), which can later encourage describing the phenomena that occur. Miralles et al. (2012) viewed a person's attitude as reflected in independence and stability in self-actualization, which later can be the key to shaping self-actualization and forming intentions. 
Rameikiene and Startiene (2013) stated that a person's attitude arises at the beginning of the mind. It must be created with positive and accurate information so that the attitudes and intentions are as expected. Krueger et al. (2000) mentioned that intention is an excellent indicator to describe behaviour. This is because the ability to describe the best conditions is carried out. Nieuwenhuizen and Swanepoel (2015) said that positive intention is a way of thinking that describes the opportunity for a person's good attitude. Therefore the hypothesis proposed was:

H1: Attitude has a significant effect on Growth Intention

\section{Injunctive Norm toward Growth Intention}

The injunctive norm indicates that behaviour is triggered by a person's desire to act as a result of the preferences of those around him (the environment) in how one must act. In this model, subjective norms reflect the potential effects of the social circle of SME actors to shape perceptions and encourage SME actors to continue to grow. Some literature proposes a positive relationship between subjective norm (Injunctive norm) with behavioural intentions. Kim et al. (2013) explains that there is a close relationship between subjective norms on entrepreneurial intention, which supports the hypothesis.

Injunctive norms are related to norms determining behaviour related to something that other people want them to do. Norms are intended to describe in predicting intentions; this is due to the intention of someone, someone who orders or orders from other parties (Wong, 2019). In general, decision norms have two parts that always influence effectively, namely from family and friends groups (Rivis and Sheeran, 2003). The injunctive norm has different indicators that can support its success, where America tends to be more obedient to orders from governments in Asia (Smith et al. 2012). This provides support that the environment can support the formation of intentions. Ajzen (2002); Ham et al. (2015) revealed that decision norms are closely related to subjective norms. This is due to the ability to encourage orders of intentions and behaviour. When the orders are clear and enforceable, it encourages the order-to-order, and the appropriate behaviour is expected.

The injunctive norm of the person is related to an important person who provides an image to form the intention to behave. Accordingly, the individual must have the ability to explain the expectations they have (Ashakenazi et al. 2005). The formation of intention, which can be successful by the party, when the person is willing to follow orders, can encourage intention (Park and Smith, 2007). Several important indicators related to norms of the commandment, namely: 1) Sharing opinions; 2) Important information; and 3) Support for such information. The injunctive norm can predict the intention to carry out an activity, where someone who believes in another person (friend) will follow the order even though the prediction is not significant (Zaleski, 2013). In adolescents, that command norms play a role in ordering behaviour that is in line with what is ordered. On the other hand, this is the belief (Cialdini et al. 1991). This view is successful when the number of commands is large, and this is due to the number of individuals who can convey the truth of the message conveyed to form behaviour (Barber et al. 1999). Behaviour for a better life can be supported with positive intentions, this previously needs to be supported by the right orders. The accuracy of orders has several indicators, including 1) suitability and 2) clarity (Finlay et al. 2002). Predictions of intentions and behaviour can be predicted and run as expected when the individual who receives the message or order believes in the message conveyed, this can increase the expected impact (Terry and Hogg, 1996). Fishbein et al. (1995) stated that the norms of command can intervene in society, but in this case, it needs to be done in some time so that all messages conveyed can be implemented properly by all elements of society. Cialdini et al. (1990) found that messages to influence others need to be made in detail but briefly so that information intended to influence a person can be conveyed and have an impact on increasing the intention to do something. The norm of hurting, according to (Dillard and Shen, 2005), can be conveyed when the information is conveyed in a good persuasive manner. In the end, norms that are detrimental to situations can encourage intentions and behaviours that produce large reactances so that these can be effective for messengers (Reid and Aiken, 2013).

In critical conditions, the injunctive norm plays a role in increasing awareness and intention to be better, and this is indicated by an issue that is widespread in society (Farias and Pilati, 2020). Chung and Rimal (2016) declared that this is motivated by the instructions and understanding of the individual in the message conveyed. The injunctive norm can be successful and has a significant impact when there is a referral from the closest person (family and friends). This impact can be 
different if it is delivered from a distant group of people (Farias and Pilati, 2020). Therefore, the hypothesis proposed was:

H2: Injunctive norm has a significant effect on Growth Intention

\section{Descriptive Norms toward Growth Intention}

Descriptive Norms are perceptions of what other people do (Schlagel \& Koenig, 2014). Descriptive norms determine what most people do in certain situations, as well as the behaviour that most people do. In previous studies, it was obtained that descriptive norms significantly increased variance in intentions (contributing $5 \%$ to TPB theory). In terms of understanding the intention of SME actors to improve their efforts, this descriptive norm provides an overview of the extent to which descriptive norms that are not as strong/rigid as the Injunctive norm can affect the intention of SME actors to develop.

Descriptive norms are descriptions related to beliefs that come from oneself, especially descriptions of intentions and behaviour (Forward, 2009). The basic descriptive norm originates when combined with subjective norms so that this becomes more complete (Ajzen and Fishbein, 2005). On the other hand, this has received opposition from some experts related to the amalgamation of subjective norms and descriptive norms, which are caused by different things (Cialdini et al. 1990; Deutsch and Gerrard, 1955; Grube et al. 1986). The impact of descriptive norms related to intention and behaviour. this can be because of the individual, the information conveyed, as well as other important factors (Rivis and Sheeran, 2003). Forward (2009) added that demographics explain messages, intentions and good behaviour.

Rimal et al. (2005) revealed that descriptive norms are not more subtle when compared to command norms, this is because descriptive norms try to use an approach from self-awareness directly and based on perceptual messages from the individual. Kobis et al. (2015) clarified that self-confidence that descriptive norms are based on the perceptions of individuals who often abuse environmental awareness and behaviour. Rima and Real (2003) found that a person's benchmark for having intentions and decisions is characterized by descriptive norms, this is due to the ability to make someone aware of an important problem.
According to Erikson et al. (2015), ethical and appropriate behaviour of individuals can be described from descriptive norms, where this is an important part of being able to describe someone to show what is common in society. Information should be built based on descriptive norms because it can have a stronger impact but needs to be built with a longer time, unlike the faster command norms (Schoolly et al. 2005). Kobis et al. (2015) stated that descriptive norms build social evidence that leads to similar behaviour so that in this case it becomes evident that when a location is filled with the same individuals. Mair and Bergin (2010) found that all intentions and attitudes based on descriptive norms will be more responsible, this is because they are chosen consciously so that they have a big impact on internal consistency. Goldstein et al. (2007) and Schultz et al. (2007) explained that descriptive norms derived from subjective norms can encourage stronger attitudes in having intentions. Based on Cialdint et al. (1990), these actions can encourage other people to act like someone who acts normally, in this case indicating that these norms act and work as a result of external roles. Therefore the hypothesis proposed was:

H3: Descriptive norm has a significant effect on Growth Intention

\section{Perceived Behavior Control toward Growth Intention}

PBC is defined as self-perception of the level of ease or difficulty in performing certain behaviours. In other words, Neneh \& Vanzyl (2014) stated the extent to which a person holds control in performing a behaviour with experience preferences. Ajzen indicator shows that perceived behaviour control holds a subjective level of control over the performance of the behaviour and distinguishes perceived behaviour control from the same perception of the actual behaviour that will produce the desired results. Therefore, perceived behaviour control is the ease or difficulty felt by SMEs' entrepreneurs to improve their business. Support for the role of PBC on intention and behaviour is provided as a result of research by (Kim et al. 2013; Ajzen \& Fishbein, 1980).

PBC is the process of organizing, interpreting the stimuli received by a person to make something meaningful for the individual (Walgito, 2004). PBC is the final process of observation which is initiated by the sensory process, which is the process of receiving a stimulus by the senses, then passing it on to the brain, and only then do 
individuals become aware of something they perceive (Sunaryo, 2004). Perceived, according to Kotler (2004), is a process used by individuals to select, organize, and interpret information input to create images so that they have meaning. Garvin (2007) explained that there are 5 important indicators in the formation of perceived, namely: 1) Performance; 2) Reliability; 3) Features; 4) Conformance; and 5) Ability.

PBC can be felt when controlled properly, this is related to limitations by linking some basic things in the object being assessed (Andryani and Kurniawati, 2015). Golnaz et al. (2010) explain that the formation of perceptions can be classified by several groups, where it is intended to strengthen the role of forming the intentions and attitudes of individuals. Experts identify perceived behaviour control as a description of the control of individuals on internal and external factors to have intentions and attitudes (An-Nahdi et al. 2015). The information obtained by the subject has an impact on the formation of PBC, if this can be maintained then the individual will tend to have a strong intention to own the object (Alam and Sayuti, 2011). Bagher et al. (2018) showed that individuals can: 1) Control attitudes and make decisions; 2) Individuals who have resources tend to meet needs; and 3) Individuals who have time will tend to allocate time to get the objects needed.

The formation of PBC related to self-efficacy is related to judgments about whatever action a person can take (Bandura, 1982). PBC is part of the individual's belief in determining easy or difficult performance on behaviour (Chang and Ching, 2011). Armitage and Conner (2001) explained that it is necessary to have a perceived control behaviour to create intention, but in this case, it requires a bridge in the connected variable.

Irianto and Haryanto (2011) explained that perceptions of behaviour control do not affect intention, due to lack of awareness of information. In the millennial era, it is known that the intention and behaviour of using technology need to be supported by PBC (Gangadharbatla, 2008). The importance of the perceived influence of PBC on attitudes and attitudes, a concept related to the ability to believe in something that happens and to appreciate it (Kolvereid, 1996). Bang et al. (2000) explained that individual beliefs are related to ordering self-control and the intention to do something. This is shown from the description of behaviour that can be better controlled to perform better (Chen et al. 1998).
May et al. (2009) explain that perceived behaviour control is closely related to morals, this is due to good intentions. Mcgee et al. (2009) explained that PBC is a person's belief in his or her ability to successfully launch a business activity. Chen et al. (1998) explained that someone who is given a relevant task can have an impact on behaviour, this is because the individual has greater control. $\mathrm{PBC}$ is related to perception, this is due to the belief to form the resources needed to create more appropriate behaviour (Ajzen, 1991). Ajzen and Fishbein (1975) argued that inner control refers to the desire to perform a certain behaviour, this is due to the individual probability dimension in the environment between self and behaviour. Thus, the hypothesis proposed was:

H4: PBC has a significant effect on Growth Intention

\section{Implication Managerial}

In this study, it is known that several important things can have major implications in increasing interest in entrepreneurship. It is known that several parties can be involved in increasing interest in entrepreneurship, namely: 1) The government can make a stimulus by issuing policies, especially related to training and financing. In addition, it increases the participation of the incubator so that it will accelerate success; 2) The private sector cooperating with the government provides space for the owners of SMEs to help run their businesses.

\section{CONCLUSIONS AND RECOMMENDATIONS}

\section{Conclusions}

This research that uses a literature study approach (previous research) can provide an overview of the influence of each variable of attitudes, injunctive norms, descriptive norms, and Perceived Behavioral Control on growth intentions. This study provides additional literature that determines the interest in developing a business, not only using the TPB (Attitude, Subjective Norm, Perceive Behavior Control) theory. However, with this study, it is known that the factors forming growth intention are Attitude, Injunctive Norm, Descriptive Norm and Perceive Behavior control. So that this study can explain better the factors forming growth intention than the TPB theory (McEachan et al. 2016). 


\section{Recommendtions}

Future studies are expected to use SEM to export and test the causal relationship between constructs. Then a moderating effect can be added to explain the relationship between constructs. In addition, it can classify the types of MSMEs from the growth in number and turnover to provide an overview related to the advantages of a region.

\section{REFERENCES}

Adrianto NM. 2020. Perceived value, attitude towards ad, dan purchase intention pada iklan emosional coca cola. Jurnal Ilmiah Manajemen Fakultas Ekonomi 6(2):221-236.

Ajzen I, Fishbein M. 1975. Belief, Attitude, Intention and Behaviour:An introduction to Theory and Research. California:Addison-Wesley.

Ajzen I. 1991. The theory of planned behavior. Organi Behavior Human Decision Process 50(2):179211.

Ajzen I. 2002. Perceived behavioral control, selfefficacy, locus of control, and the theory of planned behavior. Journal of Applied Social Psychology 32(1): 665-683.

Ajzen L, Albarracin D, Hornik R. 2007. Prediction and Change of Health Behavior. London:Taylor \& Francis

Ajzen L. 2012. Martin fishbein's legacy:The reasoned action approach. The ANNALS of the American Academy of Political and Social 2(2):21-33.

Ajzen MI, Fishbein. 1980. Understanding Attitudes and Predicting Social Behaviour. New Jersey:Practice Hall

Alam SS, Sayuti NM. 2011. Applying the theory of planned behavior (tpb) in halal food purchasing. International Journal of Commerce and Management 2(1):8-20.

Alferaih. 2017. Weight- and meta-analysis of empirical literature on entrepreneurship. Journal Business Resolution 112(1):541-548.

Al-Nahdi TS, Habib SA, Bakar AH, Bahklah MS, Hassan O, Al-Attas HA. 2015. The effect of attitude, dimensions of subjective norm, and perceived behavior control, on the intention to purchase real estate in saudi arabia. International Journal of Marketing Studies 7(5):120-131.

Andryani D, Kurniawati. 2015. Pengaruh attitude, subjective norm, perceived behavioral control pelanggan non-muslim terhadap intention to purchase. Seminat Nasional Cendikiawan 1(1):674-681.

Armitage CJ, Conner M. 1999. The theory of planned behaviour:assessment of predictive validity and perceived control. British Journal of Social Psychology 38(1):35-54.

Ashkenazi T, Guttman N, Hornick J. 2005. Signing on the dotted line. Marketing Health Services 25(1):19-25.

Bagher AN, Salati, F, Mohammad Ghaaffari. 2018. Factors affecting intention to purchase organic foof products among iranian consumer. Academy of Marketing Studies Journal 2(3):1-23.

Bandura A . 1982. Self-efficacy:mechanism in human agency. American Psychologist 37(2):122-147.

Bang HK, Ellinger AE, Hadjimarcou J. Traichal PA. 2000. Consumer concern,knowledge, belief, and attitude toward renewable energy:an application of the reasonedaction theory. Psychology \& Marketing 17(6): 449-468.

Bank Indonesia, LPPI. 2015. Profil Bisnis Usaha Mikro, Kecil dan Menengah (UMKM). Jakarta:Bank Indonesia dan LPPI.

Barber JG, Bolitho F, Bertrand LD. 1999. The predictors of adolescent smoking. Journal of social service research 26(1):51-66.

Bosma N, Kelley D. Global entrepreneurship monitor; Global Report 2018/2019. London:Global Entrepreneur Monitor.

Chang CC, Ching YC. 2011.Comparing consumer complaint responses to online and offline environment. Internet Research 21(2):124-137.

Charan KMP, Singh P, SN. 2018. Relationships among social capital, self-efficacy, and new venture creations. Managemen Decision 56(1):204-218.

ChenCC, GreenePG,CrickA.1998. Doesentrepreneurial selfefficacy distinguish entrepreneurs from managers?. Journal of Business Venturing 13(4): 295-316.

Chung A, Rimal RN. 2016. Social norms:a review. Review of Communication Research 4(2016): 145.

Cialdini B, Kallgren C, Reno R. 1990. A focus theory of normative conduct:recycling the concept of norms to reduce littering in public places. Journal of Personality and Social Psychology 58(6):1015-1026.

Cialdini RB, Kallgren CA, Reno RR. 1991. A focus theory of normative conduct:A theoretical refinement and reevaluation of the role of norms 
in human behavior. Advances in Experimental Social Psychology 1(2): 201-234.

Deutsch M, Gerard HB. 1955. A study of normative and informational influences upon individual judgement. Journal of Abnormal and Social Psychology 51(1955):629-636.

Dillard JP, Shen L. 2005. On the nature of reactance and its role in persuasion. Communication monographs 72(2):144-168.

Dong BH, Selcuk SS. 2009. Many roads lead to Rome:How entrepreneurial orientation and trust boost the positive network range and entrepreneurial performance relationship. Industrial Marketing Management 88(2):173185.

Erikson T, Knockaert M, Der Foo M. 2015. Enterprising scientists:the shaping role of norms, experience and scientific productivity. Technological Forecasting and Social Change 99(1): 211-221.

Farias J, Pilati R. 2020. Violating social distancing amid the COVID-19 pandemic:Psychological factors to improve compliance. Violating Social Distancing 1(1):1-45.

Fayolle A, Linan F. 2014. The future of research on entrepreneurial intentions. Journal Business Resolutin 67(5):663-666.

Finlay KA, Trafimow D, Villareal A. 2002. Predicting exercise and health behavioral intentions:Attitudes, subjective norms, and other behavioral determinants. Journal of Applied Social Psychology 32(2): 342-356.

Fishbein M, Trafimow D, Middlestadt SE, Helquist M, Francis C, Eustace MA. 1995. Using an AIDS KABP survey to identify determinants of condom use among sexually active adults from St. Vincent and the Grenadines. Journal of Applied Social Psychology 25(1) :1-20.

Forward SE. 2009. The theory of planned behaviour:The role of descriptive norms and past behaviour in the prediction of drivers' intentions to violate. Transportation Research Part 12(2009):198207.

Gangadharbatla H. 2008. Facebook me:collective selfesteem, need to belong, and internetself-efficacy as predictors of the iGeneration's attitude toward social networking sites. Journal of Interactive Advertising 8(2):5-15.

Garvin, Davis. 2007. Manajemen Mutu Terpadu. Jakarta: Erlangga.

Gay PL, Diehl. 1992. Research Methods for Business and Management. New York:MacMillan
Publishing Company.

Gieure CM, Espinosa MB, Dobon SR. 2020. The entrepreneurial process:The link between intentions and behavior. Journal Business Resolution 112(11):541-548.

Goldstein N, Cialdini R. 2007. Using Social Norms as a LevelofSocialInfluence[Tesis].Philadelphia:The Science of Social Influence:Advances and Future Progress.

Golnaz R, Mohammed Z, Shasudin MN, Chiew EFC. 2015. Non-muslims' awareness of halal principles and related food products in malaysia. International food research journal 17(3):1-11.

Grube JW, Morgan M, McGree ST. 1986. Attitudes and normative beliefs as predictors of smoking intentions and behaviours:a test of three models. British Journal of Social Psychology 25(1986): 81-93.

Guerrero M, Rialp J, Urbano D. 2008. The impact of desirability and feasibility on entrepreneurial intentions:A structural equation model. International Entrepreurship Management Journal 4(1):35-50.

Ham M, Jeger M, Ivkovic AF. 2015. The role of subjective norms in forming the intention to purchase green food. Economic ResearchEkonomska Istraživanja 28(1):738-748.

Hussein Z, Oon SW, Fikry A. 2017. Consumer attitude:does it influencing the to use mhealth. Procedia Computer Science 105(2017):340 344.

Irianto H, Haryanto B. 2011. Niat konsumen dalam pembelian makanan organik. Jurnal Kinerja Bisnis dan Ekonomi 15(1):73-87.

Kim E, Ham S, Yang IS, Choi JG. 2013. The roles of attitude, subjective norm, and perceived behavioral control in the formation of consumers' behavioral intentions to read menu labels in the restaurant industry. International journal hospitality management 35(1):203-213.

Köbis N C, Prooijen VJW, Righetti F, Van Lange PAM. 2015. "Who doesn't?"-The impact of descriptive norms on corruption. PLoS One. 10(1):1-11.

Kolvereid L. 1996. Prediction of employment status choice intentions/Entrepreneurship:Theory \& Practice 21(1): 47-57.

Kotler K 2004. Manajemen Pemasaran:Analisis, Perencanaan, Implementasi Dan Kontrol. Jakarta:Prenhallindo.

Krueger, N, Reilly MD. Carsrud AL. 2000. Competing 
models of entrepreneurial intentions. Journal of business venturing 15(1):411-432.

Lee EB, Lee SG, Yang CG. 2017. The influences of advertisement attitude and brand attitude on purchase intention of smartphone advertising. Industrial Management \& Data Systems 117(6):1-30.

Mahfud T, Triyono MB, Sudira O, Mulyani Y. 2020. The influence of social capital and entrepreneurial attitude orientation on entrepreneurial intentions:the mediating role of psychological capital. European Research on Management and Business Economics 26(1):33-39.

Mair J, Seers SB. 2010. The effect of interventions on the environmental behaviour of australian motel guests. Tourism and Hospitality Research 10(4):1-11.

Mappigau P. 2012. Entrepreneurial intention and small business growth :an empirical study of small food processing enterprises in South Sulawesi, Indonesia. Entrepreneurship Intent Small Business 2(4):237-248.

May DR, Luth M. Schwoerer CE. 2009. The effects of business ethics education on moralefficacy, moral meaningfulness, and moral courage:a quasiexperimental study. Academy of Management Proceedings 1(1):1-6.

Mc Gee JE, Peterson M, Mueller SL. Sequeira JM. 2009. Entrepreneurial selfefficacy:refining the measure. Entrepreneurship Theory and Practice 33(4):965-988.

McEachan R, Taylor N, Harrison R, Lawton R, Gardner P, Conner M. 2016. Meta-analysis of the reasoned action approach (raa) to understanding health behaviors. Annals of Behavioral Medicine 50(4):592-612.

Miralles F, Riverola C, Giones F. 2012. Analyzing nascent entrepreneurs'behaviour through intentionbasedmodels. Paper presented at the ISPIM Conference. Barcelona: La Salle University.

Moy JW, Luk VWM. 2003. The life cycle model as a framework for understanding barriers to SME growth in Hong kong. Asia Pasific Business Revolution 10(2):199-202.

Mueller S. 2011. Increasing entrepreneurial intention:Effective entrepreneurship course characteristics. Small Business Economic 32(4):351-374.

Neneh BN, Vanzyl J. 2014. Growth intention and its impact on business growth amongst SMEs in
South Africa. MediteraniaJournal Social Science 5(20):172-183.

Nicolaides A. 2011. Entrepreneurship - the role of higher education in South Africa. Educational Research 2(4):1043-105.

Nieuwenhuizen C, Swanepoel E. 2015. Comparison of the entrepreneurial intent of master's business students in developing countries:South Africa and Poland. Acta Commercii 1(1): 1-10.

OECD. 2018. Strengthening SMEs and entrepreneurship for productivity and inclusive growth. SME Minist. Conf. Key Issues Pap 1(February): $1-2$.

OECD. 2019. OECD SME and Entrepreneurship 2019. Paris:OECD.

Park HS, Smith SW. 2007. Distinctiveness and influence of subjective norms, personal descriptive and injunctive norms, and societal descriptive and injunctive norms on behavioral intent:a case of two behaviors critical to organ donation. Human Communication Research 33(2): 194-218.

Reid AE, Aiken LS. 2013. Correcting injunctive norm misperceptions motivates behavior change:a randomized controlled sun protection intervention. Health Psychology 32(5):551-560.

Remeikiene RD, Startiene G. 2013. Explaining entrepreneurial intention of university students:The role of entrepreneurial education. International Proceedings of the Management, Knowledge and Learning International Conference 2013. 299-307.

Rimal RN, Lapinski MK, Cook RJ, Real K. 2005. Moving toward a theory of normative influences:How perceived benefits and similarity moderate the impact of descriptive norms on behaviors. Journal of Health Communication 10(2): 433-450.

Rimal RN, Real K. 2003. Understanding the influence of perceived norms on behaviors. Communication Theory 13(1):184-203.

Rivis A, Sheeran P. 2003. Descriptive norms as an additional predictor in the theory of planned behavior:A meta-analysis. Current Psychology 22(3):218-23

Rivis A, Sheeran P. 2003. Social influences and the theory of planned behaviour:evidence for a direct relationship between prototypes and young people's exercise behaviour. Psychology and Health 18(a):567-583.

Rosiana L, Hubeis M, Cahyadi ER. 2020. Factors affecting user behavior of technology application 
of management information system. Indonesian Journal of Business and Entrepreneurship 6(3):239-247.

Sanchez JC. 2014. Entrepreneurship:Introduction. Pricothema 23(3):424-430.

Schlaegel C, Koenig M. 2014. Determinants of Entrepreneurial Intent:A Meta-Analytic Test and Integration of Competing Models. Entrepreneur Theory Practival 38(2):291-332.

Scholly K, Katz AR, Gascoigne J, Holck PS. 2005. Using social norms theory to explain perceptions and sexual health behaviors of undergraduate college students:an exploratory study. Journal of American College Health. 53(2005): 159-166.

Schult P, Nolan JM, Cialdini R, Goldstein N, Griskevicius V.2007. Theconstructive, destructive and reconstructive power of social norms. Psychological Science 18(5): 429-434.

Shapero A. 1982. The Encyclopedia of EntrepreneurshipThe Encyclopedia of Entrepreneurship. Newyork:Springer.

Smith JR, Louis WR, Teryy DJ, Greenaway KH, Clarke MR, Cheng X. 2012. Congruent or conflicted? The impact of injunctive and descriptive norms on environmental intentions. Journal of Environment Psychology 32(2012):353-361.

Sunaryo. 2004. Psikologi Untuk Keperawatan.
Jakarta:EGC.

Terry DJ, Hogg MA. 1996. Group norms and the attitude-behavior relationship:A role for group identification. Personality and Social Psychology Bulletin 22(2):776-793.

Turker D, Selcuk SS. 2009. Which factors affect entrepreneurial intention of university students? Journal of European Industrial Training 33(2):142-159.

Walgito B. 2004. Pengantar Psikologi Umum. Jakarta: Andi.

Wicklund E. 2014. Why doctors still have reservations about mHealth?, Nairobi:MobiHealthNews.

Wiklund J, Patzelt H, Shepherd DA. 2009. Building an integrative model of small business growth. Small Business Economic 32(4) :351-374.

Wong N. 2019. Injunctive and descriptive norms and theory of planned behavior:influencing intentions to use sunscreen. Women's Health and Complications 2(1):1-7.

Zaleski AC, Young A, Patricia A. 2013. Using peer injunctive norms to predict early adolescent cigarette smoking intentions. Journal of Applied Social Psychology 43(1):E124-E131. 